\title{
PERILAKU SOSIAL JALAK BALI (Leucopsar Rothschildi Stresemann 1912) DI KANDANG PERKEMBANGBIAKAN UNIT PENGELOLAAN KHUSUS PEMBINAAN JALAK BALI TEGAL BUNDER TAMAN NASIONAL BALI BARAT
}

\author{
Social Behavior Jalak Bali (Leucopsar Rothschildi Stresemann 1912) at Special \\ Breeding Coop Of Development Management Unit Jalak Bali Tegal Bunder West Bali \\ National Park \\ Sonia Wulandari, Andi Chairil Ichsan, Maiser Syahputra \\ Jurusan Kehutanan Fakultas Pertanian Universitas Mataram \\ JI Pendidikan No 37 Mataram Nusa Tenggara barat \\ Email: wulandarisonia3@gmail.com
}

\begin{abstract}
Management of breeding activities consists of feed aspect, sex ratio, reproduction, health, and other needs. Jalak social behavior in UPKPJB Tegal Bunder consists of 9 behaviors consisting of interdisciplinary behavior, approaching each other, making out, marrying, cleaning the beak, chasing each other, pecking each other, mutual voices and nursery care. From the observation, there is some male and female behavior. The highest social behavior is performed by females about 420 times, while males are about 388 times during observation time.Keywords: Jalakbali, breeding management, social behavior
\end{abstract}

Keywords: Jalak Bali, breeding management, social behavior

\begin{abstract}
ABSTRAK
Kegiatan pengelolaan manajemen penangkaran terdiri dari aspek pakan, sex ratio, reproduksi, kesehatan dan kebutuhan lainnya. Perilaku sosial jalak bali di UPKPJB Tegal Bunder terdiri dari 9 perilaku terdiri dari perilaku saling menelisikbulu, saling mendekati, bercumbu, kawin, membersika paruh, saling mengejar, saling mematuk, saling bersuara dan memelihara anakan. Dari hasil pengamatan terdapat beberapa perilaku jantan dan betina. Perilaku sosial tertinggi dilakukan oleh betina sekitar 420 kali, sedangkan jantan sekitar 388 kali selama waktu pengamatan.
\end{abstract}

Kata Kunci: Jalak bali, pengelolaan penangkaran, perilaku sosial

\section{PENDAHULUAN}

Jalak bali (Leucopsar rothschildi Stresemann 1912) merupakan famili sturnidae. Habitat alami burung tersebut hanya terletak di Taman Nasional Bali Barat. . Kekhasan dan keindahan bulu serta kicauan suaranya menyebabkan burung jalak bali diminati banyak orang untuk diperdagangkan, sehingga ancaman laju kepunahannya meningkat dari waktu ke waktu. 
Alikodra (1987) mengungkapkan bahwa penurunan populasi jalak bali disebabkan oleh beberapa faktor diantaranya perburuan liar, kebakaran hutan dan kerusakan habitat karena aktivitas manusia. Kondisi tersebut mengakibatkan populasinya terancam punah. Pemerintah Indonesia telah menetapkan burung jalak bali sebagai salah satu jenis burung yang dilindungi (PP No. 7 Tahun 1999). Peraturan padaperdagangan internasional burung jalak bali (Leucopsar rothschildi) masuk pada daftar Appendix I CITES (Convention on International Trade in Endangered Species of Wild Fauna and Flora) dan merupakan satwa kategori kritis menurut IUCN (International Union for the Conservation of Nature and Natural Resources). Oleh sebab itu, untuk menjaga kelestarian jalak bali dilakukan upaya konservasi melalui konservasi diluar habitat alami (exsitu).

Usaha peningkatan populasi jalak bali di Taman Nasional Bali Barat dilakukan melalui pembentukan Unit Pengelolaan Khusus Pembinaan Jalak Bali Tegal Bunder (UPKPJB). Unit pengelolaan ini merupakan penangkaran dalam konsep semi alami dengan tujuan menghasilkan jalak bali yang masih memiliki kemurnian genetik, sehingga tidak merubah perilakunya. Selain itu, upaya kelestarian dan keberadaannya di alam dapat dipertahankan. Kegiatan pengelolaan manajemen penangkaran yang dilakukan terkait aspek pakan, sex ratio, reproduksi, kesehatan dan kebutuhan lainnya. Menurut Ameliah (2015) menyatakan bahwa data perilaku satwa merupakan dasar utama dalam keberhasilan kegiatan manajemen penangkaran. . Salah satu perilaku pada satwa liar adalah perilak sosial. Berdasarkan pemikiran tersebut bahwa penelitian ini dilakukan dengan tujuan mengetahui perilak sosial jalak bali (Leucopsar rothschildi Stresemann 1912) di kandang perkembangbiakan (UPKPJB) Taman Nasional Bali Barat.

\section{METODE}

Penelitian ini dilaksanakan di Unit Pengelolaan Khusus Pembinaan Jalak Bali (UPKPJB) Tegal Bunder Taman Nasional Bali Barat. Penelitian dilaksanakan selama 10 hari yaitu pada pada tanggal 25 Februari 2018 sampai 6 Maret 2018. Alat yang digunakan antara lain jam tangan, tally sheet, web cam, alat tulis, dan kamera digital. Objek dalam penelitian ini sepasang jalak bali, yaitu jalak bali betina, jalak bali jantan, serta anakan jalak bali yang di tangkarkan di kandang perkembangbiakan. Pengamatan serta pencatatan perilaku sosial Jalak Bali dilakukan dengan metode ethogtram. Ethogram merupakan sebuah daftar pengamatan yang dikategorikan ke dalam jenis perilaku yang ditimbulkan oleh hewan selama pengamatan. Ethogram dapat digunakan sebagai panduan dalam pengamatan perilaku hewan (Orzech, 2005). Pengamatan perilaku sosial selama 10 hari merujuk pada Kurniawan(2014). Pencatatan dilakukan berdasarkan jam aktif jalak bali yaitu pada pukul 06.00 - 18.00 WITA merujuk pada (Azis, 2013).

Pencatatan dilakukan dengan interval 5 menit merujuk pada Sutrisno (2000). Pemilihan obyek dalam penelitian ini menggunakan kaidah focal animal sampling. Focal animal sampling yaitu pengambilan data tingkah laku satwa dengan menggunakan individu tertentu (Martin dan Bateson 1993). Pengkategorian perilaku sosial dalam penelitian ini merujuk pada Azis (2013), Febri (2014), Ichsan A (2018), Rekapermana et al (2006), Gitta (2011), Ameliah(2015) terdiri dari saling menelisik bulu, saling mendekati, bercumbu, kawin, membersihkan paruh, saling mengejar, saling mematuk, saling bersuara dan memelihara anakan (memberi makan anakan). Pemilihan sampel dalam penelitian ini dilakukan menggunakan kaidah PurposiveSampling. Purposive Sampling adalah teknik penentuan sampel dengan pertimbangan tertentu (Sugiyono, 2015). Penentuan sampel dilakukan berdasarkan kriteria menurut Mas'ud (2010) yaitu kriteria indukan jalak bali yaitu sehat (aktif), nafsu makan baik, mata jernih, bulu halus, usia minimal 2 
tahun, tidak cacat, bersuara lantang. Penentuan sampel kandang ditentukan berdasarkan beberapa kriteria menurut Setio dan Takandjanji (2007) yaitu, berada pada tempat yang aman, jauh dari keramaian, mudah diawasi dan mudah dicapai, dan fasilitas kandang yang memadai.

Data tentang aspek teknis penangkaran dianalisis secara deskriptif dan kuantitatif dengan cara menguraikan semua aspek teknis yang dipraktekkan dalam pemeliharaan jalak bali di UPKPJB. Adapun data tentang perilaku sosial jalak bali dianalisis secara deskriptif juga dianalisis secara kuantitatif. Gambaran umum perilaku diperoleh dengan penghitungan persentase setiap perilaku serta melihat tingkat frekuensi perilaku yang dilakukan oleh jalak bali. Persentase frekuensi dan durasi setiap perilaku dihitung dengan mengacu (Martin dan Bateson, 1988):

$$
\text { Persentase frekuensi perilaku }(\%)=\frac{A}{B} \times 100 \%
$$

Keterangan: $A$ :Jumlah frekuensi suatu perilaku

B :Jumlah seluruh frekuensi perilaku

\section{HASIL DAN PEMBAHASAN}

\section{Perilaku Sosial}

Perilaku sosial yang ditemukan selama pengamatan yaitu perilaku saling menelisik bulu antar indukan, menelisik bulu anakan, saling mendekati antar indukan, saling mendekati anakan, bercumbu, kawin, membersihkan paruh indukan, membersihkan paruh anakan, saling mengejar antar indukan, mengejar anakan, saling mematuk antar indukan, mematukan akan, saling bersuara dan memelihara anakan (memberi makan anakan). Dari hasil pengamatan diketahui perilaku sosial yang dilakukan oleh jantan diantaranya perilaku saling bersuara, saling mendekati, memberi makan anakan, saling menelisik buku, bercumbu, saling mengejar, saling mematuk, mendekati anakan, menelisik bulu anakan, mematuk anakan dan mengejar anakan. Burung yang betina melakukan perilaku sosial diantaranya yaitu perilaku saling bersuara, saling mendekati, memberi makan anakan, saling menelisik buku, bercumbu, saling mengejar, saling mematuk, saling membersihkan paruh, mendekati anakan, menelisik bulu anakan, mematuk anakan dan mengejar anakan dan membersihkan paruh anakan. Hasil pengamatan menunjukkan bahwa perilaku sosial lebih banyak dilakukan oleh betina daripada jantan. Hal tersebut diduga karena jantan kurang melakukan aktivitas sosial terhadap anakan karena kemungkinan burung jalak bali sudah memasuki masa reproduksi sehingga lebih agresif. Sama halnya dengan pendapat Houpt dan Thomas (1982) yang menyatakan bahwa pada umumnya satwa jantan lebih agresif dibandingkan dengan satwa betina, baik dalam hubungan interspecies maupun intraspecies.

Secara umum, kondisi suatu habitat dapat memberikan pengaruh terhadap perubahan perilaku satwa sebagai bagian dari proses adaptasi satwa terhadap kondisi lingkungan barunya. Hal ini berarti, setiap satwa selalu melakukan proses belajar (learning process) untuk dapat beradaptasi dengan lingkungan baru sebagai bagian dari usaha mempertahankan hidupnya (Hafez 1969 diacu dalam Satriyono 2008).

Burung jalak jalak bali merupakan burung yang hidup berkelompok, biasanya burung jalak bali akan terbang atau melakukan aktivitas bersama sebelum memasuki musim kawin. Jalak bali hidup berkelompok sebanyak 4-40 ekor (Mas'ud, 2010). Dari hasil pengamatan bahwa perilaku sosial tertinggi antar indukan yaitu perilaku saling bersuara, saling mendekati, dan saling menelisik bulu. Bersuara merupakan perilaku yang penting. Hal ini didukung oleh Rianti 
(2012) mengatakan bahwa bersuara atau berkicau dilakukan untuk mempertahankan diri serta memikat betina dalam proses perkawinan. Selain itu, perilaku saling mendekat merupakan perilaku sosial kedua terbanyak yang dilakukan burung. Sesuai dengan Mas'ud (2010) mengemukakan bahwa perilaku saling dekat dilakukan oleh pasangan jalak bali jantan dan jalak bali betina menandakan bahwa jalak bali tersebut sudah terbentuk pasangan. Perilaku saling menelisik bulu merupakan perilaku yang dilakukan burung untuk merapikan dan membersihkan bulu dari kotoran-kotoran yang menempel. Azis (2013) menyatakan bahwa aktivitas saling menelisik tubuh dilakukan oleh jalak bali yang telah masuk kedalam musim kawin. Persentase perilaku antar indukan dapat dilihat pada Gambar 1.

\section{Perilaku Sosial antar Indukan Jalak Bali}

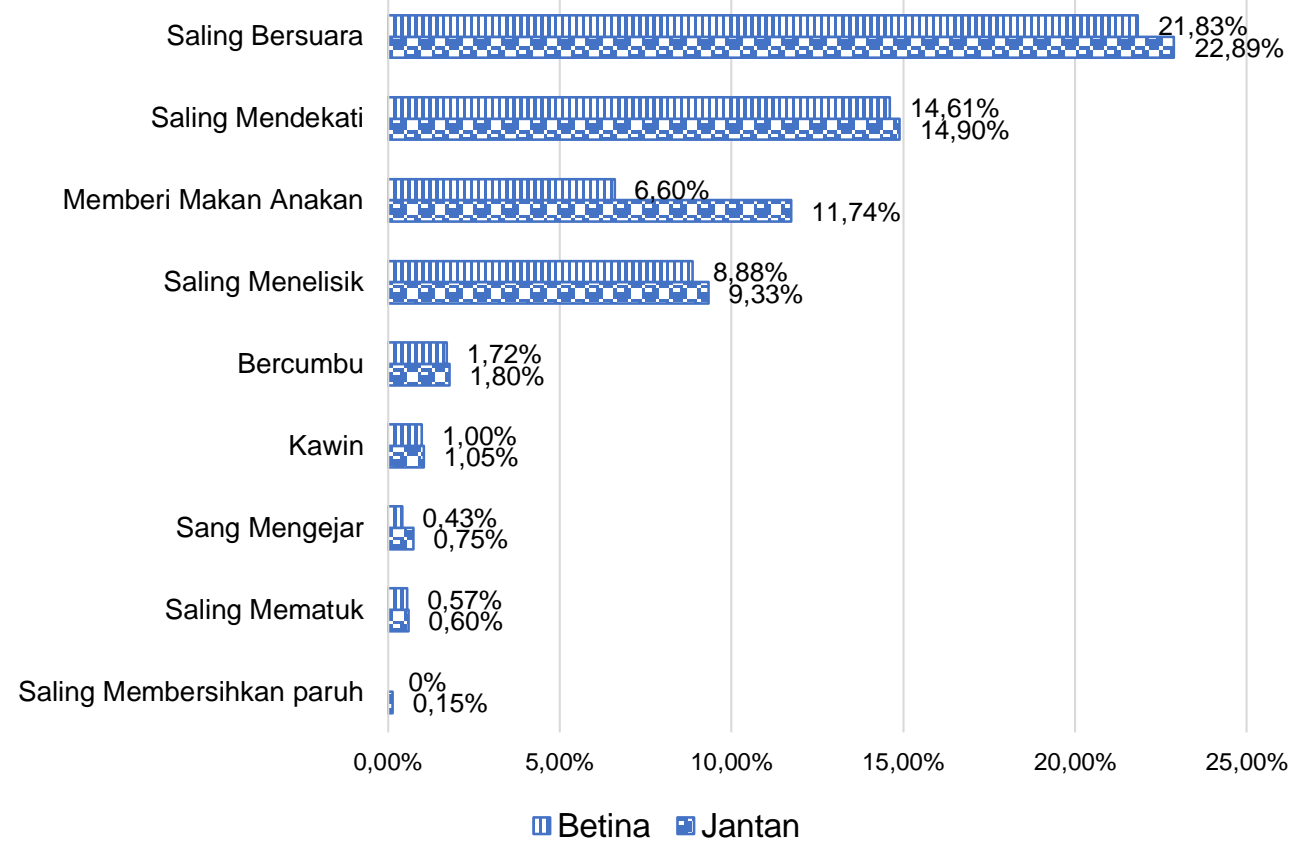

Gambar 1. Kurva persentase perilaku sosial jalak bali berdasarkan jenis kelamin di penangkaran Figure 1. The percentage curve of social behavior for Jalak Bali based on sex in captivity

Gambar diatas menunjukan bahwa Perilaku mendekati merupakan perilaku yang banyak dilakukan induk jantan maupun betina, namun persentasi perilaku mendekati anakan lebih banyak dilakukan oleh induk betina yaitu $275.78 \%$ dan jantan $20.33 \%$. Selain perilaku mendekati anakan, induk terlihat melakukan perilaku mengejar anakan, namun presentasi perilaku mengejar anakan pada induk lebih tinggi (1.05\%) dibandingkan betina $(0.28 \%)($ Gambar 2). Mas'ud (2010) menyatakan bahwa jalak bali jantan lebih agresif dibandingkan betina saat memasuki masa reproduksi.

Oleh sebab itu, berdasarkan hasil penelitian tersebut maka yang harus dilakukan yaitu memisahkan indukan dengan anakan agar tidak terjadi kematian terhadap anakan. Hal ini didukung oleh Ameliah (2015) bahwa tujuan penyapihan memberikan kesempatan kepada indukan untuk bertelur lagi, supaya lebih produktif. Penyapihan perlu dilakukan sesegera mungkin untuk menghindari kematian anak, karena terkadang induk jalak bali memiliki perilaku membuang anak/ tidak mengasuh anak (Mas'ud, 2010). Berdasarkan hasil pengamatan bahwa 
kegiatan penyapihan anakan di UPKPJB dilakukan saat usia anakan berumur 37 hari. Ameliah (2015) menyatakan bahwa anakan yang berumur 25-30 hari sudah mampu mengambil pakan sendiri

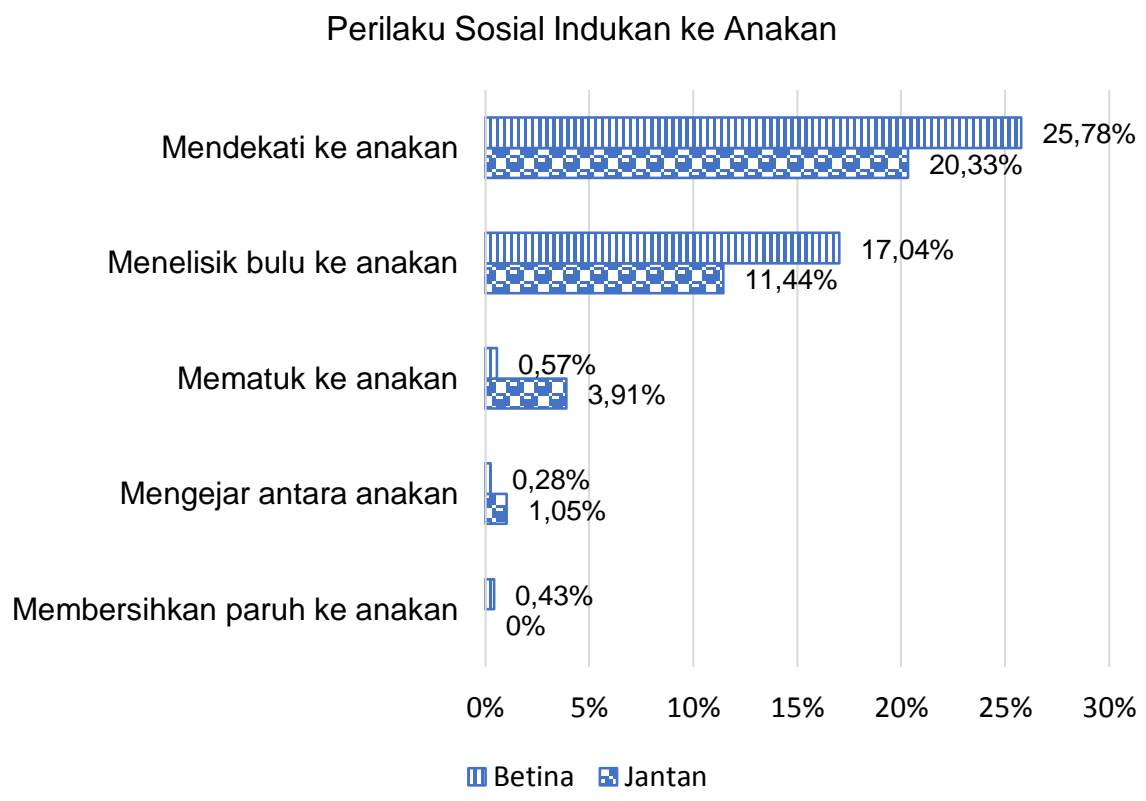

Gambar 2. Kurva persentase perilaku sosial jalak bali terhadap anakan berdasarkan jenis kelamin di penangkaran

Figure 2. The percentage curve of social behavior of Bali starlings against sex-based tillers in captivity

\section{KESIMPULAN}

Perilaku sosial jalak bali di UPKPJB terdiri dari perilaku saling menelisik bulu antar indukan, menelisik buluanakan, saling mendekati antar indukan, saling mendekati anakan, bercumbu, kawin, membersihkan paruh indukan, membersihkan paruh anakan, saling mengejar antar indukan, mengejar anakan, saling mematuk antar indukan, mematuk anakan, saling bersuara dan memelihara anakan (memberi makan anakan). Perilaku sosial tertinggi yaitu perilaku saling bersuara, saling mendekati anakan, memberi makan anakan dan saling menelisik bulu sedangkan perilaku social terendah antar indukan yaitu perilaku perilaku saling mengejar dan perilaku membersihkan paruh antar indukan dan perilaku sosial tertinggi pada anakan yaitu perilaku mendekati dan menelisik bulu anakan.

\section{DAFTAR PUSTAKA}

Azis, AS. 2013. Teknik penangkaran dan aktivitas harian jalak bali di Penangkaran UD Anugrah Kediri Jawa Timur [skripsi]. Bogor (ID) :Institut Pertanian Bogor.

Afnan, EMA.2009. Studi Karakteristik Dan Preferensi Habitat MacanTutulJawa (Panthera pardus melas Cuvier, 1809) di Taman Nasional Ujung Kulon. [skripsi] .Bogor (ID): Institut Pertanian Bogor 
Alikodra, HS. 2002 Pengelolaan Satwaliar Jilid I. Yayasan Penerbit Fakultas Kehutanan IPB. Bogor

Alikodra, HS. 1987. Masalah pelestarian jalak bali. Media Konservasi 3(4).

Ameliah, SA. 2015. Perilaku Perkembangbiakan Burung Jalak Bali (Leucopsar rotschildi Stresemann 1912) Dalam Penangkaran Di Safari Bird Farm Nganjuk Jawa Timur.[skripsi]:Bogor.Fakultas Kehutanan Institut Pertanian Bogor

Balen, Dirgayusa IWA, Putra IMWA, Prins HHT. 2000. Status and distribution of the endemic Bali Starling (Leucopsarrothschildi). Oryx 34(3): 188197.

Chalmer, N. 1980. Social behaviour in primates. University Park Press:Baltimore.

Campbell, NA, Reece, JB, dan Nitchel, LG. 2004. Biologi. Edisi Kelima jilid 3.Penerbit Erlangga. Jakarta

Febri. 2014. Manajemen Penangkaran Dan Aktivitas Harian Kakatua Sumba (Cacatua sulphuera citrinocristata) di Penangkaran Mega Bird And Orchid Farm Bogor, Jawa Barat [skripsi].Bogor:Fakultas Kehutanan Institut Pertanian Bogor

Gitta, A. 2011. Teknik penangkaran, aktivitas harian dan perilaku makan burung kakak tua-kecil jambul kuning (Cacatua sulphurea sulphurea Gmelin,1788) di Penangkaran Burung Mega Bird and Orchid Farm, Bogor, Jawa Barat [skripsi]. Bogor: Fakultas Kehutanan Institut Pertanian Bogor.

Ichsan, A. (2018). Kajian Penggunaan Ruang Dan Waktu Rusa Totol (Axis Axis ) Di Lingkungan Istana Bogor Jawa Barat Study of Spatial Use and Time of Deer (Axis axis) in Bogor Palace Environment. West Java. Jurnal Hutan Tropis, 6(1), 63-72.

doi:http://dx.doi.org/10.20527/jht.v6i1.5106

Jamaksari, H.2011. Keanekaragaman Burung Pantai Pada Berbagai Tipe Habitat Lahan Basah Di Kawasan Muara Cimanuk, Jawa Barat [skripsi]. Bogor. Fakultas Kehutanan Institut Pertanian Bogor.

Kurniawan, H. 2014. Teknik Penangkaran dan Perilaku harian Jalak Putih di Mega Bird And Orchid Farm Bogor Jawa Barat [skripsi]. Bogor: Fakultas Kehutanan Institut Pertanian Bogor.

Martin, P, Bateson P. 1993. Measouring Behavior An Introduction Guide 2nd Edition. Cambridge: Cambridge University Press.

Matono, N. 2010. Metode Penelitian Kuantitatif (Analisisisi dan analisis data Sekunder ) PT. Raja Grafindo Persada. Jakarta

Mas'ud, B. 2010. Teknik Menangkarkan Burung Jalak di Rumah. Bogor: IPB press.

Nazir. 2011. Metode Penelitian. Ghalia Indonesia. Bogor

Odum, EP. 1993. Dasar-dasar Ekologi Edisi Ketiga. Yogyakarta: Uniersity Gadjah Mada Press

Pandanwati, D. 2009. Perilaku Yang Berhubungan Dengan Aktivitas Makan Bajing Tiga Warna (Callosciurus prevostii) Pada Siang Hari di Penangkaran [skripsi]. Bogor. Fakultas Peternakan. Institut Pertanian Bogor.

Putra, CA. 2016. Pengunaan Habitat dan Perilaku Burung Pantai Migran di Pesisir Pantai Timur Deli Serdang Provinsi Sumatera Utara [tesis]. Bogor. Sekolah Pasca Sarjana. Instutut Pertanian Bogor.

Rekapermana, M, Thohari, M, Masy'ud, B. 2006. Pendugaan jenis kelamin menggunakan ciriciri morfologi dan perilaku harian pada gelatik jawa (Padda oryzivora Linn, 1758) di penangkaran. Media Konservasi 9(3): 89-97.

Rahayu, W.2009. Ensiklopedia Fauna Khas Indonesia.PT. Mediantara Semesta.Jakarta

Smuts, BB, Cheney DL, Seyfarth RM. Wranghan RW, Struhsaker TT.1987. Primate Societes . Chicago: The University of Chicago Press

Scott, JP. 1963. Animal Behavior. Chicago (US): The University of Chicago Press

Sungkawa, W. et al. 1974. Pengamatan Jalak Putih (Leucopsar rothchildi) di Taman Perlindungan Alam Bali Barat. Laporan LPH, Bogor, No, 195 
Suwelo, SI. 1976. Studi Habitat dan Populasi Jalak putih di Suaka Alam Bali Barat. Laporan Universitas Nasional Jakarta (Lembaga Ekologi) dan PPA, Bogor

Sawitri, R, Takandjandji M. 2010. Pengelolaan dan perilaku burung elang di Pusat Penyelamatan Satwa Cikananga, Sukabumi. Jurnal Penelitian Hutan dan Konservasi Alam Vol. 7 No. 3: 257-270.

Setio, P, Takandjanji, M. 2007. Konservasi ex-situ burung endemik langka melalui penangkaran. Prosiding Ekspose Hasil-hasil Penelitan; Padang, 20 September 2006. Bogor; Pusat Penelitian dan Pengembangan Kehutanan dan Konservasi Alam

Suryawan, W. 2004. Penangkaran Jalak Bali (Leucopsar rothschildi) di Penangkaran Taman Nasional Bali Barat. Taman Nasional Bali Barat. Cekik-Bali.

Sutrisno, E. 2000. Beberapa Aspek Ekologi Burung Wilwo Mycteriacinerea (Raffles) di Segera Anakan Cilacap [skripsi]. Bogor. Fakultas Kehutanan. Institut Pertanian Bogor.

Thohari, M. 1987. Upaya Penangkaran Satwa liar. Media Konservasi 1(3): 21-26.

Takandjandji, M, Mite M.2008. Perilaku burung beo alor di penangkaran Oilsonbai, Nusa Tenggara Timur. Buletin Plasma Nutfah 14 (1): 43 - 48.

Takandjandji, M, Kayat, Njurumana GND. 2010. Perilaku burung bayan sumba (Electusroratus cornelia Bonaparte) di penangkaran Hambala, Sumba Timur, Nusa Tenggara Timur. Jurnal Penelitian Hutan dan Konservasi Alam 3 (4): 357-369.

Wiens, F.2002. Behavior dan ecology of wild slow lorises (Nycticebuscoucang): social organization, infant care system dan diet [disertasi]. Bayreuth (DE): Bayreuth University.

Warsito, H. 2010. Teknik Penangkaran Burung Mambruk (Goura sp.). Bogor: Pusat Penelitian dan Pengembangan Hutan dan Konservasi Alam.

Waluyo, J et al. 2009. Buku Informasi Curik Bali. Gilimanuk

Yusuf, M. 2014. Metode Penelitian (Kuantitatif, kualitatif \& penelitian Gabungan). Prena Media Group. Jakarta 